\title{
INCOME TAX "LOOPHOLES" AND POLITICAL RHETORIC
}

\author{
Boris I. Bittker*
}

\section{INTRODUGTION}

$\mathrm{D}$ URING the 1972 presidential campaign, federal income tax reform came unexpectedly to the foreground as a political issue in the Democratic primaries and promised for a few weeks to play an important role in the election itself. It was soon elbowed aside by the prospect of peace in Viet Nam, charges of political espionage and corruption, and attacks on the personal attributes of the two candidates, but for a short time it actually succeeded in crowding school bussing off the front pages. To the cynic, this might in retrospect seem to be the principal accomplishment, if not the purpose, of the vivid charges that the Internal Revenue Code is riddled with loopholes and that millionaires sometimes pay less in taxes than bluecollar workers. I am inclined, rather, to believe that these grievances continued to smoulder below the surface, like the issue of school bussing, even after President Nixon and Senator McGovern turned their attention to other questions.

Moreover, just as hostility to school bussing emanated from a variety of sources, so the assault on tax loopholes brought together some strange bedfellows. Advocates of a "New Populism" wanted to close loopholes in order to strengthen the income tax as a tool of income redistribution. Academic experts, who supplied most of the intellectual ammunition for the tax reform movement, wanted to purge the income tax of its imperfections primarily to insure "horizontal equity"; for most of them, increased progressivity was only a secondary objective, and some were prepared to accept, or even to advocate, a less progressive rate structure if that was the legislative cost of tax reform. Welfare reformers who wanted to replace today's welfare system with a guaranteed-income program thought that their proposals could be financed by closing tax loopholes. For still others, tax loopholes were only symptoms of a worse disease-a federal bureaucracy serving the interests of the very rich and the very poor but financed by those in between. Their remedy was to cut back

- Sterling Professor of Law, Yale University. B.A. 1938, Cornell University; LL.B. 1941, Yale University.-Ed.

Copyright (c) by Boris I. Bittker.

This Article is an expanded and revised version of the first of three lectures given by the author in the Thomas M. Cooley Lecture series, University of Michigan Law School, on April 4, 5, and 6, 1973. 
federal expenditures, rather than to close the loopholes in order to support or increase the offensive programs.

"Tax reform" could serve as the rallying cry of forces that had little else in common because it is irretrievably ambiguous. In academic circles, to be sure, "income tax reform" almost invariably refers to proposals to expand the tax's coverage, but the term can also be used as a label for proposals to narrow its scope or scuttle it entirely. The same ambiguity surrounds the term "social change," which candidates for admission to law school like to offer as the motive that animates their interest in practicing law-with no apparent acknowledgement that Vice-President Agnew may be as dedicated to social change as they, but in a different direction.

A similar source of ambiguity is the catchy charge that the federal income tax is so full of loopholes that it constitutes a vast "welfare program for the rich." 1 Though intended as a call for heavier taxes on capital gains, state and municipal bond interest, and the oil industry, this allegation panders to a popular distaste for the "welfare mess," whether its beneficiaries are rich or poor. The same rhetorical device was employed by President Nixon, but with a better feel for public reaction, when he alleged that Senator McGovern's tax reform proposals would add 82 million people "to the welfare rolls."2 The instrument that was to accomplish this result was the Senator's famous $\$ 1,000$ tax credit or "demogrant," a technical device that he was unable to explain in the headlines, but that, unfortunately, he could not erase from them either. The very label "demogrant" invited comparison with a welfare grant, and President Nixon can hardly be blamed for seizing on the parallelism at a time when tax scholars have been asserting that tax allowances, including the basic personal and dependency exemptions, are the equivalent of subsidies or grants of public funds to the taxpayer. ${ }^{3}$

Another example of the coalescence of rhetoric can be seen in the allegation by the authors of $A$ Populist Manifesto that the federal income tax authorizes "legal larceny," 4 a phrase that is virtually iden-

1. Stern, Uncle Sam's Welfare Program-for the Rich, N.Y. Times, April 16, 1972, \$ 6 (Magazine), at 28, col. 2. See also P. Stern, The RApe OF THE TAXpayer (1973).

2. N.Y. Times, Aug. 24, 1972, at 47, cols. 2-3.

3. See Heller, Some Observations on the Role and Reform of the Federal Income Tax, in 1 House Comm. on Ways and Means, 86 Th Cong., Ist SEss., TAx Revision Compendium 181, 190 (Comm. Print 1959); Pfaff \& Pfaff, How Equitable Are Implicit Public Grants?, in ReDistribution to the RIGH AND THE POOR 181 (K. Boulding \& $M$. Pfaff ed. 1972); Surrey, Tax Incentives as a Device for Implementing Government Policy: A Comparison with Direct Government Expenditures, 83 HARv. L. REv. 705 (1970). See also Bittker, Accounting for Federal "Tax Subsidies" in the National Budget, 22 NATL. TAX J. 244 (1969) and articles cited in id. at 244-45 nn.1-4.

4. J. Newfiesd \& J. Greenfield, A Populist Manifesto 97 (Warner Paperback Library ed. 1972). 
tical with John Chamberlin's charge, from the right wing, that the Sixteenth Amendment "legalizes a theft." 5 The targets of the latterday populists are the loopholes for the rich, of course, but they do not have a copyright on this complaint. A tract calling for repeal of the Sixteenth Amendment (appealingly entitled The Income Tax: Root of All Evil), for example, also alleges that "pressure groups" are responsible for "loopholes," that the rich get around the law with the aid of "expert accountants," that we now "soak the poor" more than the rich, ${ }^{8}$ and that salvation lies with a coalition of workers, housewives, professional people, and small businessmen, since "the big industrialists, bankers, and commercial interests . . . have no reason to favor repeal [of the Sixteenth Amendment]."9 It has even been suggested, in language echoing the argument in Pollock v. Farmers' Loan \& Trust Company ${ }^{10}$ (which held the 1894 federal income tax unconstitutional and was in turn overruled by the Sixteenth Amendment), that today's income tax is "unconstitutionally discriminatory," and that a "taxpayers' liberation movement" should appeal to the courts, since both Congress and the Treasury have turned a deaf ear to taxpayers' grievances. ${ }^{11}$

Barraged by assertions that the rich have conspired to tax the income of the poor while exempting themselves, the working man may conclude that he would prefer a sales tax-a preference that has already been exhibited by rank-and-file voters in the few states that still lack a state income tax. In a 1972 public opinion survey commissioned by the Advisory Commission on Intergovernmental Relations, for example, almost twice ( 46 per cent versus 25 per cent) as many respondents preferred a state sales tax to a state income tax as a source of substantial additional revenue; when asked to name the nation's "fairest" tax, they named the state sales tax about as often as the federal income tax ( 33 per cent versus 36 per cent), while the state income tax was chosen by only 11 per cent of the respondents. ${ }^{12}$ At the federal level, this attitude may well lead to enactment of a federal valueadded tax, which would be a national sales tax in disguise-a consummation that the new populists would surely deplore.

5. Chamberlin, Book Review, 21 U. CHI. L. Rev. 502, 505 (1954).

6. F. Chodorov, The Income TAX: Root of All Evil 66-67 (1954).

7. $I d$, at 67 .

8. Id. at 51-52.

9. Id. at 108 .

10. 157 U.S. 429 (1895).

11. Halby, 1s the Income Tax Unconstitutionally Discriminatory?, 58 A.B.A.J. 1291, 1292 (1972).

12. U.S. Advisory Commn. on Intergovernmental Relations, Public Opinion and TAXES 7-10 (1972). 
I do not wish by these observations to suggest that critics of the Internal Revenue Code should suppress their reformist instincts lest they get bitten by dogs that are now sleeping peacefully. Nor would I deny the usefulness of political slogans. As Niebuhr has said, "Contending factions in a social struggle require morale; and morale is created by the right dogmas, symbols and emotionally potent oversimplifications." 13 The prudent strategist, however, will avoid slogans and rhetoric that can be captured by the enemy and used in a successful counterattack. But this is not a manual on political strategy. My purpose, rather, is to examine the "loopholes" that dominate the discussion of federal income tax reform.

When used by newspaper reporters and politicians, the term "tax loophole" is always a pejorative, though the tone of disapproval may be mingled with a dash of admiration for the astute lawyer or accountant who discovered the device. Since condemnation is the predominant tone, it is always assumed that loopholes can be quickly and reliably distinguished from tax provisions that are reasonable and fair. Sometimes, to be sure, it is suggested that the only criterion is self-interest: one man's loophole is another man's relief provision. More frequently, loopholes are said to inure primarily, if not solely, to the benefit of the rich, either because high-priced experts must be employed to devise loophole-exploiting transactions or because it takes capital to consummate the plan after a tax-free route has been discovered. Finally, it is often thought that tax loopholes entail an enormous loss of potential governmental revenue, and that their eradication would either permit everyone else's taxes to be reduced or provide the funds for social welfare programs of great magnitude. Each of these issues deserves scrutiny.

\section{Statu'tory Ambiguities and Omissions}

The term "tax loophole" is often used to denote a flaw in the language of the Internal Revenue Code or in the Treasury Regulations, discovered by a sharp-eyed lawyer or accountant and exploited by his clients. In popular mythology, indeed, the major activity of tax experts is the search for divergencies between the letter of the law and its spirit, somewhat as W. C. Fields described his purpose in reading the Bible: "Looking for loopholes, of course, looking for loopholes." This usage accords with the Oxford English Dictionary's definition of "loophole" as "an ambiguity or omission in a statute, etc., which affords opportunity for evading its intention."14 Result-

13. R. NIEbuHR, MORAl MAN ANd IMmoral SOcIETY Xv (1948).

14. 6 The Oxford English Digtionary 433 (1933). There is, of course, a vast body 
ing by hypothesis from a legislative error, a loophole in this sense is likely to be corrected by Congress once it comes to public attention; the phrase "notorious loophole" is thus either a contradiction in terms or a transitory phenomenon. When discovered by a tax expert, therefore, a loophole is a wasting asset that he must exploit quickly but warily. His clientele must be informed of his discovery if he is to reap a financial benefit from it, but when he exposes it to view, he reduces its life expectancy by stimulating Congress to enact corrective legislation. His dilemma resembles that of the archeologist whose excavation brings an ancient fresco to light but simultaneously exposes it to the destructive forces of nature.

For its part, the Treasury must also make a difficult decision when it discovers a loophole. A request for corrective legislation will call attention to the statutory imperfection and stimulate taxpayers to exploit it in the interim, but if the Treasury seeks to discourage such attempts by announcing that the ambiguity or omission is more apparent than real and hence should not be relied on by taxpayers, Congress may refuse to take action on the ground that the need for legislation has not yet been demonstrated. A leading tax publication, for example, once announced that "for months ... the tax fraternity has been aware that the Treasury had a list of loopholes in the law that it considered too hot to release, for fear of encouraging taxpayers to flock to use these tax-saving devices." 15

Loopholes of this type-statutory ambiguities and omissions so clearly in conflict with the intent of the legislature ${ }^{16}$ that prompt correction can be expected as soon as they come to light-are, in my opinion, not very common. One example (chosen because it is not excessively technical) is a 1954 provision $^{17}$ that permitted the taxpayer to take a dependency deduction for a member of his household whose principal place of abode was the taxpayer's home, even if the dependent was not related to the taxpayer by blood, marriage, or adoption-relationships that had previously been indispensible to a dependency exemption. Intended by Congress to permit foster chil-

of case law and commentary on legislative "intent," "purpose," and "motive," and the view that these are fictional concepts is less prevalent than it was two decades ago. See J. Cohen, Materials and Problems on Legislation 35-186 (2d ed. 1967); A. Lenhoff, Comments, CASEs and Other Materiats on Legislation 577-85, 787-854 (1949).

15. 28 of Treasury's Famous Secret Loopholes and Hardships Revealed by Ways \& Means Committee, 5 J. TAXATION 322 (1956). See also STAFF OF JolNT Comm. ON INternal Revenue Taxation, 84th Cong., 20 Sess. \& Staff of Treasury Department, List of Substantive Unintended Benefits and Hardships and Additional Problems FOR THE Technical AMENDMENTS AcT BiLl of 1957 (1956); Technical Amendments Act of 1958, Pub. L. No. 85-866, 72 Stat. 1606.

16. See text accompanying note 14 supra.

17. INT. REv. CoDE of 1954, \& 152(a)(9). 
dren to qualify as dependents, the language of the new provision held out the tantalizing possibility that the taxpayer could deduct $\$ 600$ a year for the cost of supporting a mistress or kept man. Before this incentive to what would now be called an alternative life style got very far, however, the courts shot it down. Invoking "the well settled rule that statutes should receive a sensible construction, so as to effectuate the legislative intention and, if possible, avoid an absurd conclusion," the Tax Court held:

In our opinion Congress never intended the specific paragraph in question to be construed so literally as to permit a dependency exemption for an individual whom the taxpayer is maintaining in an illicit relationship in conscious violation of the criminal law of the jurisdiction of his abode.

We are of the opinion that to so construe the statute would in effect ascribe to the Congress an intent to countenance, if not to aid and encourage, a condition not only universally regarded as against good public morals, but also constituting a continuing, willful, open, and deliberate violation of the laws of the State of Alabama. . . . This we are unable to do. ${ }^{18}$

The Tax Court's surmise about the legislative intent was subsequently confirmed by Congress, which amended the Code in 1958 to provide explicitly in section $152(\mathrm{~b})(5)$ that a person whose relationship to the taxpayer violates local law is not to be treated as "a member of the taxpayer's household." Recommending enactment of this language, the Senate Finance Committee described it as declaratory of the law ("[I]t is made clear that ....") ") rather than as a substantive change, and provided that it would be retroactively effective as of 1954, when the ambiguous provision creating the problem entered the Code. ${ }^{20}$ Along with this clarification of the law, Congress closed another loophole in section 152(a)(9) by amending it to provide that the taxpayer may not claim his spouse as a dependent, since such a deduction (although arguably sanctioned by the original language of this provision ${ }^{21}$ ) would ordinarily duplicate a deduction for the taxpayer's spouse that was already authorized by another provision of the Code (section 151). Here again, Congress denied that it was making a substantive change, asserting instead that the legislation was intended only " $[t]$ o make it clear that [the loophole] was

18. Turnipseed v. Commissioner, 27 T.C. 758, 760-61 (1957).

19. S. REP. No. 1983, 85th Cong., 2d Sess. 15 (1958).

20. Act of Aug. 16, 1954, ch. 736, $\$ 152(a)(9)$, 68A Stat. 49 (codified at INT. Rev. CODE OF 1954, \& 152(a)(9)).

21. Act of Aug. 16, 1954, ch. 736, § 152(a)(9), 68A Stat. 43. 
not at any time intended" and reinforcing this explanation by providing that the new language was to be applied retroactively. ${ }^{22}$

For another example of a loophole arising from inept draftsmanship, I turn to the Connecticut tax on capital gains, which, after exempting $\$ 2,000$ of such gains in specified circumstances, goes on to provide that the $\$ 2,000$ exemption is to be multiplied by a fraction, the numerator and denominator of which are then described in terms not here relevant. ${ }^{23}$ The legislative purpose was to reduce the $\$ 2,000$ exemption to a lesser amount or even to zero in certain circumstances. But the draftsman forgot, or perhaps never knew, that a fraction can be greater than $1 / 1$, as well as smaller. By failing to provide that the exemption might in no case exceed $\$ 2,000$, he opened the door to an exemption of many times that amount-indeed, to an exemption of unlimited amount-when the statutory fraction exceeds $1 / 1$. Another case of inadvertance-also drawn from the Connecticut statute books-is the inadvertent omission of the word "not" from a provision defining the term "resident" for tax purposes. ${ }^{24}$

In cases like these, the courts often come to the rescue by holding that the letter of the law is not controlling, and that the legislative purpose-gleaned from the statute's history or context, or inferred by comparing the practical consequences of the competing interpretations-must prevail over the scrivener's deficiency. A 1940 opinion of the United States Supreme Court describes this process succinctly:

There is, of course, no more persuasive evidence of the purpose of a statute than the words by which the legislature undertook to give expression to its wishes. Often these words are sufficient in and of themselves to determine the purpose of the legislation. In such cases we have followed their plain meaning. When that meaning has led to absurd or futile results, however, this Court has looked beyond the words to the purpose of the act. Frequently, however, even when the plain meaning did not produce absurd results but merely an unreasonable one "plainly at variance with the policy of the legisla-

22. S. REP. No. 1983, supra note 19, at 15. This action in effect endorsed a prior judicial decision refusing to permit a deduction for the spouse under section 152(a)(9), despite its language, because the over-all statutory scheme when illuminated by its legislative history showed "that it was not the intention of the Congress to grant an additional exemption" for a dependent spouse. Dewsbury v. United States, 146 F. Supp. 467, 469 (Ct. Cl. 1956). See also Rev. Rul. 55-325, 1955-1 Cum. Bull. 18.

23. CONN. GeN. STAT. ANN. \&12-506(c)(1) (1972).

24. No. 5, § I(b)(1), [1971] Conn. Pub. Acts June Spec. Sess. 2173, from which the bracketed word was omitted: "or who is [not] domiciled in this state but ..." The error became a matter of only academic interest when the entire act was repealed, later in the same session, by No. 8, \& 1, [1971] Conn. Pub. Acts June Spec. Sess. 2245. 
tion as a whole" this Court has followed that purpose, rather than the literal words. ${ }^{25}$

This approach is well illustrated by the Tax Court's comments in the dependency exemption case, summarized above, to which numerous other examples could be added.

The courts are not always this candid in admitting that the words are being twisted a little to get at the substance lying below the surface. In Helvering $v$. Owens, ${ }^{26}$ for example, the Supreme Court had to pass on the amount to be deducted as a casualty loss when the taxpayer's automobile was slightly damaged in a collision. He had paid about $\$ 1,800$ for the car, but it was worth only $\$ 225$ before and $\$ 190$ after the accident. Although only $\$ 35$ of damage was attributable to the collision, the statutory language seemed clearly to permit the taxpayer to deduct the difference between the car's original cost and its value after the accident, or over $\$ 1,600$ on these facts. The Court of Appeals for the Second Circuit so decided, in a per curiam opinion bearing every indication of Judge Learned Hand's authorship: "[T] he letter is too plain; we should have to disregard the words, and should not be interpreting them, if we refused to take them just as they read." 27 In a substantially identical case, however, the Court of Appeals for the Fourth Circuit parted company with Judge Hand, asserting that "it is not reasonable to suppose that Congress intended to permit [a] deduction in excess of actual loss" and that "the statute should be construed as containing such exception[s] where necessary to avoid a consequence which Congress clearly did not intend."28 The Supreme Court, reviewing both cases, ${ }^{29}$ endorsed the Fourth Circuit's reading of the statute but buried the issue in a cloud of verbiage rather than admitting that it was stretching the statutory language. This should not, however, obscure the Court's implicit determination to reach an eminently sensible result despite the draftsman's ineptitude.

Since loopholes, as I have been using the term, depend for their existence on a judicial willingness to elevate the letter of the law over its substance, the kind of judicial activism just described promises to turn the loophole into an extinct art form. I do not mean to assert that the courts are never willing to enforce a badly drafted statute as

25. United States v. American Trucking Assns., Inc., 310 U.S. 534, 543 (1940).

26. 305 U.S. 468 (1939).

27. Helvering v. Owens, 95 F.2d 318, 319 (2d Cir. 1938).

28. Helvering v. Obici, 97 F.2d 431, 433 (4th Gir. 1938).

29. Helvering v. Owens, 305 U.S. 468 (1939), affg. 97 F.2d 431 (4th Cir. 1938) and revg. 95 F.2d 318 (2d Cir. 1938). 
written, or that it is already as difficult for a taxpayer to escape through a loophole as it is for a camel to squeeze through the eye of a needle. Judge Learned Hand's refusal in the Owens case to ride roughshod over the statutory language was reversed by the Supreme Court, but that does not mean that every statutory deficiency is corrected. It is an old chestnut that maxims of statutory construction come in opposing pairs, and occasionally a pair will emanate from the same author. Thus, the same Holmes who warned his fellow judges that "if [the legislature] has intimated its will, however indirectly, that will should be recognized and obeyed"30 also said, "We [judges] do not inquire what the legislature meant; we ask only what the statute means." 31 For loopholes to survive, the latter attitude must prevail.

Lacking a more systematic study of this question, I offer the hypothesis that loopholes conforming to the Oxford English Dictionary definition quoted earlier"32 ("an ambiguity or omission in a statute, etc., which affords opportunity for evading its intention") are comparatively rare. The quality of legislative drafting in the federal tax field is unusually high, the Internal Revenue Code is subject to frequent revision, and I know of no area of the law in which the courts are more likely to search for the legislative purpose and prefer it, whenever it can be discerned, to a literal construction of the statutory language. Of course, ambiguities in the tax law are sometimes resolved in the taxpayer's favor when the legislative intent is debatable, but by hypothesis these are not cases in which the legislative intent has been disregarded, however critical one may be of the substantive outcome.

Even if I overestimate the level of judicial activism, and thus underestimate the number of loopholes resulting from drafting ineptitudes that survive judicial scrutiny, it should be noted that taxpayers will continue to escape through loopholes only if Congress fails to take corrective action. If Congress fails to overrule a decision because it is content with the law as judicially interpreted, the loophole is converted into a legislatively sanctioned tax allowance. If the decision is allowed to stand only because Congress is too busy with other matters, the result can be regarded as a loophole-by-inertia. But the taxpayer who uses such an escape hatch is not so much exploiting a draftsman's error that frustrates the intent of the legislacuit).

30. Johnson v. United States, 163 F. 30, 32 (Ist Cir. 1908) (Justice Folmes on cir-

31. O. Holares, Collected Legal Papers 207 (1920).

32. See text accompanying note 14 supra. 
ture as he is benefitting from Congressional inattention or indifference. A collector of unblemished specimens will not value a loophole-by-inertia as highly as a statutory mistake that has not yet been described in the literature and is so clearly at odds with the Congressional intent that it will almost certainly evoke an amendment when it comes to public attention.

I do not want to make too much of these paradoxes, or to assert that there are no "unintended benefits" 33 in the Internal Revenue Code. No doubt it contains some loopholes in the classic sensestatutory errors that well-advised taxpayers are exploiting without the knowledge of Congress or the Treasury. No doubt some of these unintended benefits will be sustained by the courts, despite the professed judicial reluctance to allow taxpayers to make a fortress of the dictionary. No doubt some of these judicial victories will enable still other taxpayers to exploit the same mistakes because of congressional inertia.

When all is said and done, however, these are not the "loopholes" under attack. The major targets of income tax reformers are such statutory provisions as the exclusion of state and municipal bond interest from taxable income, percentage depletion, the reduced tax rate on long-term capital gains, and the deductions for local taxes, mortgage interest, and charitable contributions. These allowances have not been brought to light by the diligent burrowing of astute and highly paid tax experts seeking to frustrate the objectives of Congress. Sometimes, to be sure, tax scholars seek to enliven their prose with suggestions to the contrary. Thus, a recent study of "those hidden subsidies termed implicit public grants" 34 promises to lead us through "the jungle of provisions that convey special advantages only to the legal wizard or to the individual wealthy enough to obtain the services of a legal expert or to the person adept at manipulating potential sources of income in order to conform to some obscure section in the tax law." 35 But a conducted tour through this vividly portrayed "jungle" will disappoint the venturesome reader. Nothing more exotic will be encountered on his safari than an expensive but familiar flock of domesticated animals, of which the most prominent are the joint return for married couples, the personal and dependency exemptions, and the deductibility of charitable contributions, interest, and taxes. Far from being reserved for "legal wizards," these provisions satisfy Gibbon's description of a late

33. See note 15 supra.

34. Pfaff \&. Pfaff, supra note 3 , at 181.

35. Id. at 188 . 
Roman emperor's collection of manuscripts and concubines: "The one, as the other, was intended rather for use than ostentation." If the man in the street does not already know about these tax benefits, he can fill this gap in his knowledge by reading the Treasury's free publications or paying $\$ 5$ to a store-front tax "consultant."

\section{Tax Avoidance Tactics}

In popular usage, the term "loophole" often also reflects the widely held view that tax experts have a magical power to reduce taxes, primarily for the rich, by paperwork that has no other visible consequences. If Smith makes a series of lifetime gifts to his children in order to save death taxes by removing the property from his taxable estate, for example, the transfers may seem devoid of practical consequences because the Smiths are bound together by ties of affection that transcend their legal rights. Yet King Lear learned that family loyalties may dissolve, and even the layman who thinks that the gifts just described are nothing more than tax gimmicks might well balk if the Internal Revenue Code required him to include his teenage children's earnings when computing his taxable income. While something can be said for disregarding legal rights within the family, there is also much to be said for treating individuals as discrete units; debatable judgments are unavoidable in such an area. The concept of "family" implies a definition that includes some of the taxpayer's relatives and excludes others; no one would propose taxing the "family of man" as a single unit. Conversely, however, few are so committed to individualism as to propose that family ties be wholly disregarded in computing the individual's tax liability. The tax advantages that are inevitably conferred on taxpayers who find themselves on the tax-free side of the fence, or who get there by arranging their affairs to satisfy the law, may be called "loopholes" by the layman. So used, however, the term simply expresses disapproval of the rules; any implication that the legislative intent is being frustrated is unwarranted.

But the expert sometimes engages in another type of paperwork, similarly criticized but simultaneously admired by the layman as a species of black magic, where the implication of a conflict with the legislative intent may be better founded. I refer to transactions that are designed to fit within one statutory compartment rather than another but whose practical consequences are otherwise transitory. A taxpayer, for example, is about to sell some appreciated property with the intention of making a gift of the proceeds to his children; 
on consulting his attorney or accountant, he is advised to give the property itself to the children and let them make the sale, in order to take advantage of the fact that a donor of appreciated property is not taxed on his unrealized gain when he transfers it by gift. His hope, therefore, is that the gain will be taxed to the children, who may be subject to a lower tax rate. In such a case, and in many others that could be added to the list, the anticipated tax advantage derives from the fact that the Internal Revenue Code, despite its awesome detail, contains many provisions of such disarming simplicity as to invite manipulation. There is nothing in the Code determining whether the transaction should be taxed as a sale of property by the taxpayer followed by a gift of the proceeds by him to the children, or as a gift of the property to the children followed by a sale of the property by them. As a result, the courts must decide how the transaction is to be treated for tax purposes.

Manoeuvres as transparent as these are rarely successful, but when a bit more time elapses between one step in the transaction and another, they may get by. If so, is the taxpayer exploiting a loophole of the type discussed above, viz., a statutory ambiguity or omission that serves to frustrate the legislative intent? There are, undoubtedly, taxpayer successes that one can confidently say would have been disapproved if the issue had been exposed when the legislation was before the Congress. More frequently, however, a remedy would have been so complex that no clear legislative intent can be reconstructed from the materials at hand.

In my gift-sale case, for example, a legislative body that wished to establish a statutory rule might draw the line by establishing an arbitrary time limit (e.g., 30 days) and providing that any sale within that time by the donee should be imputed to the donor. A more restricted statutory remedy might tax the donor only if the donee is a minor child. Or the donor might be taxed only if the donee sells the property to a buyer with whom the donor had negotiated, only if the terms of the sale had been prearranged, or only if the value of the property or the tax differential between donor and donee exceeds a specified amount. Another approach would be a statutory presumption that the donee acted under the donor's influence, with an opportunity to prove instead that the donee made an independent decision to sell the property rather than keep it. When the choice of statutory remedies is as wide as this, it is impossible to say with any assurance that the disputed issue would have been resolved in one way rather than another by the legislature.

In point of fact, the courts are quite unsympathetic to avoidance 
tactics of this type. This is not the place to describe in detail the judicial doctrines that are regularly invoked to deflate ingenious and initially promising schemes, but the labels- "business purpose," "sham or camouflage," "step transactions," "form vs. substance," and the like-convey their flavor. ${ }^{36}$ Suffice it to say that the courts are quite ready in tax cases to probe beneath the surface before accepting a transaction at face value. An acerbic comment by Chief Judge John R. Brown of the fifth circuit court of appeals can stand as a summary of this attitude. Refusing to allow the taxpayers in a complex transaction to hide behind a facade entailing the use of an attorney named W. R. Deal as an intermediary, he said: "The Deal deal was not the real deal. That ends it."3r

In point of fact, the layman is far more inclined than the expert to trust paperwork as a shield against tax liability. One is bombarded at cocktail parties with tax schemes that would not convince the most inexperienced revenue agent or that teeter on the brink of fraud, but which are offered as proof positive of the speaker's astute sophistication. Randolph Paul's comments on this subject twenty years ago cannot be improved:

Above all things, a tax attorney must be an indefatigable skeptic; he must discount everything he hears and reads. The market place abounds with unsound avoidance schemes which will not stand the test of objective analysis and litigation. The escaped tax, a favorite topic of conversation at the best clubs and the most sumptuous pleasure resorts, expands with repetition into fantastic legends. But clients want opinions with happy endings, and he smiles best who smiles last. It is wiser to state misgivings at the beginning than to have to acknowledge them ungracefully at the end. The tax adviser has, therefore, to spend a large part of his time advising against schemes of this character. I sometimes think that the most important word in his vocabulary is "No" . . . .38

But not all tax experts are "indefatigable skeptics," and even those who are can sometimes be persuaded by their clients to try a tax avoidance scheme, especially if the only penalty for failure is the tax that would have been due and payable if the transaction had taken its normal course. (The deficiency in case of failure must be paid with interest, but the 6 per cent interest may be less than the value of the money to the taxpayer in the interim, and it is in any event deductible.) And these plans sometimes succeed.

36. See generally B. Bittker \& J. Eustice, Federal Income TAXation of CorporaTIONS AND SHAREHOLDERS $1-19$ to -20 (3d ed. 1971) and articles cited therein.

37. Blueberry Land Co. v. Commissioner, 361 F.2d 93, 102 (5th Cir. 1966).

38. Paul, The Lawyer as a Tax Adviser, 25 Rocky Mr. L. Rev. 412, 416 (1953). 
The layman, then, is right in thinking that business transactions are frequently cast in a particular form for no reason other than tax avoidance, that the paperwork may create a distinction without a difference, and that these formalities often succeed. Indeed, the paperwork may take the taxpayer through a tax-free route that was explicitly endorsed by Congress as an alternative to another route that is taxable. Many other tax avoidance transactions are feasible only because Congress has failed to enact a safeguard against them. Congressional inaction may reflect a judgment that the area is unimportant, that administrative and judicial scrutiny is preferable to a legislative solution, or that a satisfactory legislative remedy would be too complex; or it may stem from an unresolved difference of opinion within Congress or between Congress and the Treasury about the best remedy to be adopted or even about whether there is a defect to be remedied. Still other tax avoidance transactions are in fact vulnerable, but nevertheless escape the attention of the revenue agent if and when the return is audited. The army may have a "smart" missile that can find an airplane despite its evasive tactics, but the Internal Revenue Service has no mechanical device to unveil "the real deal" (to borrow Judge Brown's phrase), and its enforcement budget is scandalously low.

There is no harm in applying the term "loophole" to tax avoidance opportunities of the type just described, provided one does not infer from this label that they are caused by flaws in the statutory language that will be corrected as soon as they come to the attention of Congress. Moreover, however fertile this area may be as a breeding ground for "loopholes" in the layman's sense, it is not a major target of income tax reform, except to the extent that changes in the basic tax rules (e.g., in the treatment of capital gains) may reduce the opportunity for tax "planning" and "manipulation."

\section{IV. "Erosion," "Preferences," and Other Euphemisms}

Academic proponents of income tax reform have long been aware of the confusion generated by applying the term "loophole" to the major targets of their endeavors. To imply, even by a label, that they are merely exposing a series of unintended tax benefits attributable to sloppy draftsmanship belittles their crusade. It also invites a countercharge of naïveté, since the provisions in question were enacted deliberately rather than by inadvertence, and, though the results may differ from the legislative expectation, a congressional failure to amend or repeal the provisions is more likely to reflect 
legislative approval or a political stalemate than ignorance. Tax reformers, therefore, have searched for a more accurate term than "loophole" to characterize the objects of their criticism.

A veritable thesaurus of alternative labels has come into vogue in the last two decades; the most common are "exceptions," "preferences," "special privileges," "tax expenditure," and "erosion." 39 By implying that the tax benefits to which they are applied were purposefully enacted by Congress, these terms reject the aura of inadvertence and secrecy that emanates from the term "Ioophole." This, in turn, implicitly acknowledges that repeal of these provisions will not automatically follow their exposure to the light, the fate that might be hypothesized for a loophole of the classical variety. Thus, a label like "preference" or "special privilege" has the virtue of political realism, suggesting that the allowance was enacted to serve an economic interest, that it is backed by political muscle, and that it will not be relinquished without a legislative battle.

Tax commentators sometimes substitute these terms for "tax loopholes" to avoid its pejorative connotation, so that the tax benefit in question can be examined on its individual merits, without prejudgment. But this objective is rarely achieved. However impartial the writer's intent, the new label usually starts with or quickly acquires an aura of disapproval. "Erosion" can be a good thing, of course-it brought fertility to the Nile Valley and beauty to the Grand Canyon-but ordinarily it is no more welcome than an invasion of termites. As for "special privileges," they are occasionally praised-lifetime tenure for federal judges is an example-but most "privileges," particularly "special" ones, evoke enthusiastic denunciation. The term "tax expenditures" purports to be value-free, but it grows out of a theory that the direct appropriations process is presumptively a better way to confer the benefits that are embedded in the Internal Revenue Code, and it cannot escape the pejorative flavor that is unmistakably intended by its twin, "back-door spending." 40 An "exception" to a rule sometimes implies tolerance or benevolence, but more often it suggests an impropriety, unless justification is affirmatively proved; we like to think that laws should be enforced without fear or favor.

What is perhaps most notable is that none of these substitutes for the term "loophole" implies a favorable attitude. The tax pro-

39. See Bittker, A "Comprehensive Tax Base" as a Goal of Income Tax Reform, 80 HARv. L. REv. 925 (1967).

40. Heller, supra note 3 , at 190 ("The back door to government subsidies marked 'tax relief' .... .'). See also Surrey, supra note 3. 
visions in question are not described as "refinements of the tax base," as attempts to "fine-tune" the Internal Revenue Code, or as examples of tempering justice with mercy. The alternative labels are, in short, euphemisms for their predecessor.

It is not surprising, therefore, that studies by experts of tax "erosion," "preferences," and the like are regularly reported in the press under the generic title "loopholes." By itself, this stretching of labels would not matter. Headline writers are not expected to be lexicographers. But when the popular conception of "tax loopholes" - gimmicks that are invented by crafty lawyers for the very rich-is carried over to the provisions that the expert describes as "tax expenditures" or "preferences," a monumentally false impression is created.

A good example of this pervasive practice is a summary subtitle in a recent article in the New York Times Magazine which portrays "the average American taxpayer" as suffering the pains of flood and shipwreck, while the federal government dispenses "a bountiful \$77billion in 'tax welfare' each year" to "a happy few." 41 Michael Harrington has used almost identical language to denounce the Internal Revenue Code: "The unconscionable fact is that the Internal Revenue Code is a perverse welfare system that hands out $\$ 77$ billion a year, primarily to the rich." 42 These allegations and others like them are based on a statistical study of a wide range of tax allowances, published by the Joint Economic Committee in 1972. The authors are Joseph Pechman and Benjamin Okner, of the Brookings Institution, whose eminence as tax economists is exploited by the new populists to support their claim that the federal income tax dispenses $\$ 77$ billion of "tax welfare" to the rich. The carefully detailed Pechman-Okner study, however, tells a more complex and less lurid story. It shows that more than half of the $\$ 77$ billion in tax allowances goes to taxpayers with income from $\$ 5,000$ to $\$ 25,000$, and that if these provisions were repealed, almost 5 million families with income of less than $\$ 5,000$ and about the same number with income of $\$ 5,000$ to $\$ 10,000$ who now pay no income taxes would be added to the tax rolls. ${ }^{43}$ The "happy few" who profit from "erosion" of the

\footnotetext{
41. Stern, supra note 1 , at 28. Although the author refers at several points to "loopholes for the many," the central message of the article was satisfactorily summarized by the editorial captions.

42. Harrington, Ideally We Should Abolish Every Subsidy in the Internal Revenue Code, SAT. REv., Oct. 21, 1972, at 49.

43. Pechman \& Okner, Individual Income Tax Erosion by Income Classes, in JoINT Economic Commitee, 92d Cong., 2d Sess., The Economics of Federat Subsidy ProGRAMS, pt. 1, at 27 (table 8) (Comm. Print 1972), reprinted in Pechman \& Okner, Individual Income Tax Erosion by Income Classes (Brookings Institution Reprint No. 280,
} 
tax base, it turns out, are 70.5 million families-not just Middle and Upper America but most of Lower America as well.44

Pechman himself, unlike some who purport to build on his work, has made this crystal clear, pointing out "that there are loopholes for persons at all income levels" and describing the income tax as "the best tax we have." 45 Testifying before the House Committee on Ways and Means in January of 1973, Pechman said that "a great deal can be done-short of comprehensive reform-to improve the progressivity of the income tax" and offered a choice of three reform programs, which would produce revenue increases of $\$ 3.1$ billion to $\$ 10.2$ billion. ${ }^{46}$ If the Pechman-Okner study demonstrated that the federal income tax is a $\$ 77$ billion welfare program for the rich, it is hardly to be supposed that Pechman would have associated himself - even as a last resort in a poor year for tax reform-with a program that would leave $\$ 74$ of the $\$ 77$ billion unscathed.

A similar disparity between expert and popular conceptions of tax loopholes may be found in $A$ Populist Manifesto, which speaks of $\$ 50$ billion of tax "subsidies to the wealthy," describing them as "outrages legislated into the tax code" that "not a senator or congressman would have the chutzpah to vote for" if they were treated as subsidies. ${ }^{47}$ The authors then call for reforms to "close all of the loopholes in our tax law," because otherwise "the tax-dodgers and their advisers will simply move capital from one shelter to another." 48 But they refrain from listing the $\$ 50$ billion of "subsidies to the wealthy" that they nominate for wholesale extinction, and the unpublished study on which they rely discloses that the statutory "outrages" include substantially the same items that the Pechman-Okner study detailed, except for the tax benefits conferred on married couples by the joint return..$^{49}$ (The fact that the major "tax welfare"

1972). Because this study uses a broader concept of income ("expanded adjusted gross income") than existing law, many families move up the income ladder when classified by income class in the study.

44. Id.

45. Pechman, The Rich, the Poor, and the Taxes They Pay, The Public Interest, Fall 1969, at 21, reprinted in 115 CoNG. REc. 32361 (1969).

46. Hearings on General Tax Reform Before the House Comm. on Ways \& Means, 93d Cong., 1st Sess., pt. 1, at 149 (1973).

47. J. Newfieid \& J. Greenfiedd, supra note 4, at 100.

48. Id. at 105 (emphasis original).

49. Id. at 100. The "tax expenditure" list on which they rely is substantially identical with the one published in Surrey, stupra note 3, at 709-11. A later version may be found in House Committee on Ways \& Means, 92D Cong., 2D Sess., Estrmates of Federal Tax Expendrures 4-5 (Comm. Print 1972). For criticism of the tax expenditure budget, see Bittker, supra note 3; Surrey \& Hellmuth, The Tax Expenditure Budget-Response to Professor Bittker, 22 NATL. TAx J. 528 (1969); Bittker, The Tax 
lists can be separated by about $\$ 25$ billion, attributable to disagreement over the classification of one item, should suggest to the reader that both may reflect a variety of other debatable judgments, especially since a third list, with overlapping populist sponsorship, reduces the amount of "welfare to the rich" by another $\$ 25$ billion.) $)^{50}$ An even more heated-but no less misleading-denunciation of tax loopholes may be found in a discussion of white-collar crime by a professor of sociology, who accepts an earlier author's assertion that "honest payment by everybody liable to income tax would enable the government to decrease the general tax burden by 40 per cent," and then goes on to tell us that this figure "suggests rather graphically the largely unrecognized or passed over, yet very real, cost to the individual citizen of tax crimes."51

This extraordinary confusion results from the fact that the tax expert's conception of "preferences," "tax expenditures," and the like embraces many provisions that are so familiar and widespread that taxpayers often think of them as normal, if not essential, features of an income tax law. Thus, the largest single component of the $\$ 77$ billion of "tax welfare" that goes to the "happy few" is the rate advantage granted to married couples who file joint returns and the similar concessions to heads of households, to widows and widowers with minor children, and (since 1969) to unmarried persons. ${ }^{52}$ The only taxpayers who do not benefit from these provisions (which account for $\$ 21.6$ billion of the $\$ 77$ billion of "tax welfare") 53 are

Expenditure Budget-A Reply to Professors Surrey and Hellmuth, 22 NATL. TAx J. 538 (1969).

50. N.X. Times, April 15, 1973, \& 4 at 18, col. 1 (advertisement for Tax Action Campaign, described as "a project of New Populist Action"). Since the estimated $\$ 25$ billion evidently embraces the corporate income tax as well as the individual income tax, the latter's contribution to the rich must be substantially less than $\$ 25$ billion.

51. F. Schur, Our Griminal Socrety 165 (1969), referring to a statistical study described in F. Glaney, The Operators (1960). Professor Schur seems to think that the "tax crimes" which prevent the tax burden from being reduced by 40 per cent are committed primarily by business executives and large corporations, although the calculations (which Mr. Gibney advises me were given to him "by people connected with the I.R.S., who were, however, unwilling to be quoted as their source") must have been based on a tax reform program affecting tens of millions of taxpayers. (This emerges from Mr. Gibney's own statement that the amount of tax successfully evaded is about $\$ 5$ billion, a figure that would not permit the "general tax burden" to be reduced by anything like 40 per cent. $I d$. at 200.) In point of fact, both Gibney and Schur have evidently confused a reduction in tax rates with a reduction in the tax burden. A rate reducton made possible by expanding the tax base, which is the only plausible basis for Gibney's figure of $\mathbf{4 0}$ per cent, would of course leave the aggregate burden unchanged, so that some taxpayers would pay more and others less-the same result that would be produced by the Pechman-Okner proposal, see text accompanying notes 65-69 infra, to expand the base and lower the rates.

52. Pechman \& Okner, supra note 43, at 33-34 (tables A-1, A-2).

53. Id. at 33 (table A-1). 
married persons filing separate returns, who constitute less than 4 per cent of the taxpaying population. ${ }^{54}$ The next largest component in the Pechman-Okner computation, making up $\$ 14.2$ billion $^{55}$ of the $\$ 77$ billion total, reflects revenue to be raised by restricting the itemized deductions for such items as state and local taxes, medical expenses, and charitable contributions, substituting a flat $\$ 1,300$ low income allowance ${ }^{56}$ for the existing standard deduction, and repealing the extra $\$ 750$ personal exemption for persons who are over 65 or blind. The third major item (\$13 billion of $\$ 77$ billion) ${ }^{57}$ would result from the taxation of transfer payments-social security, welfare, workmen's compensation, unemployment benefits, and veterans' disability payments. Other important provisions that would be repealed or restricted by the Pechman-Okner proposals are the deductions for real property taxes and mortgage interest on personal residences and the exclusion of interest on life insurance policies.

Although all of these tax advantages are enjoyed to some extent by high income taxpayers, they accrue primarily to taxpayers in the low and middle income brackets, and these are the taxpayers whose aggregate tax liability would be most severely increased by their repeal. ${ }^{58}$ The only tax provisions of comparable fiscal importance that are monopolized by high income taxpayers (i.e., those with incomes of $\$ 50,000$ or more) are the capital gains rules (including the failure to tax appreciation on gifts and bequests), accounting for $\$ 13.7$ billion of the $\$ 77$ billion. ${ }^{59}$ High income taxpayers are also the principal beneficiaries of tax-exempt interest, accelerated depreciation, and percentage depletion, but the aggregate dollar value of these allowances ( $\$ 1.7$ billion) is minor when compared with the items described above. ${ }^{60}$

Thus, tax erosion and tax preferences are as democratic as environmental pollution: you don't have to be rich to throw a plastic beer can under a bridge, or to exclude social security benefits from your federal income tax return. Middle America may be fed up with

54. 1969 IRS, Statistics of INcome, Individual Income TAX Returns 4 (table 1C) (2.1 million taxable returns out of 63.7 million). By classifying the 1969 rate reduction for unmarried taxpayers as erosion, along with the joint rate applicable to married couples, the Pechman-Okner study, Pechman \& Okner, supra note 43, at 21 n.24, implies that there was less erosion before 1969, when the tax distance between married and unmarried taxpayers was greater.

55. Pechman \& Okner, supra note 43, at 34 (table A-2).

56. Id. at 17 .

57. Id. at 34 (table A-2).

58. Id. at 33 (table $\mathrm{A}-1$ ).

59. Id. at 34 (table A-2).

60. Id. at 23 (table 3). 
tax loopholes, as we are often told by social commentators who perceive a taxpayer revolt in their crystal balls, but only a small fraction of the $\$ 77$ billion "tax welfare" program is the target of popular outcry. Moreover, if these provisions were repealed, only 14.7 per cent of the $\$ 77$ billion yield would come from families with income over $\$ 100,000$ and 9.6 per cent from those with income from $\$ 50,000$ to $\$ 100,000.61$ Another 22.5 per cent would come from taxpayers with $\$ 25,000$ to $\$ 50,000$ of income-a group that, however well off, can hardly be classed with the Mellons and Rockefellers but whose present tax liability would have to be nearly doubled to raise their share of the target. ${ }^{62}$ This leaves more than half of the $\$ 77$ billion to be collected from taxpayers with income below $\$ 25,000$. Thus, analysis of the Pechman-Okner tax erosion study is a sobering experience. The exhilarating soak-the-rich recommendations that have been attached to it reflect the emotive power of the term "erosion," not the facts in the computer printouts.

To rebut this gloomy suggestion, it may be argued that aggregate figures are misleading. Even though half of the $\$ 77$ billion of new revenue that could be raised by applying current rates to an expanded reformed tax base would come from taxpayers with $\$ 5,000$ to $\$ 25,000$ of income and only about 15 per cent from those with incomes over $\$ 100,000$, the per capita effect of tax reform would be very different. The average tax increase for a family with $\$ 100,000$ to $\$ 500,000$ of income would be about $\$ 40,000$, while the average taxpayer at the bottom of the heap would pay only a few dollars more than he does now. ${ }^{63}$ The fact that comprehensive expansion of the tax base will cost individual rich men far more than individual poor men (so that the big loopholes are at the top) ${ }^{64}$ however, will not guarantee its popularity among the citizenry at large. However small, an increased per capita burden on low and middle income taxpayers can be painful; the last dollar may have a marginal utility to them that equals or is greater than the marginal utility of the rich man's last thousand dollars. In any event, if the issue is whether comprehensive tax reform could finance massive new federal programs, the answer is "Yes, but most of the money will come from low and middle income taxpayers."

In point of fact, though the Pechman-Okner study of erosion concluded that $\$ 77$ billion of additional revenue could be raised by

61. Id. at 26 (table 6).

62. Id.

63. Id. at 36 (table A-5).

64. Benjamin Okner, Letter to the Editor, N.Y. Times, May 8, 1972, at 32, col. 4. 
applying today's tax rates to an "uneroded" tax base (aggregate taxable income of $\$ 644$ billion, as against $\$ 478$ billion under current law), ${ }^{65}$ this was not its principal function. The study focussed, rather, on the fact that a comprehensive tax base would permit tax rates to be lowered while holding aggregate revenue constant. The statutory changes proposed by Pechman and Okner would, of course, distribute the tax burden differently than existing law even if the total amount to be collected is unchanged. Their program would, in general, increase the tax burden of homeowners relative to tenants, the burden of capital gain recipients relative to recipients of other types of income, the burden of persons itemizing their personal deductions relative to those using the standard deduction, and the burden of married persons relative to unmarried persons. Other proposals for a comprehensive tax base would have similar effects, except that some reformers are more tolerant than Pechman and Okner of the reduced rate granted by existing law to married couples.

These changes in horizontal equity (i.e., among persons on the same income level) would be accompanied by equally important changes in vertical equity (i.e., in the burdens borne by taxpayers at one income level compared with those at other levels). Because alterations in vertical equity depend upon the rate schedule to be applied to the expanded tax base, the possibilities are infinite, ranging from an extremely progressive schedule to an extremely regressive one. The Pechman-Okner study offers five alternative schedules, ${ }^{66}$ all of which might be described as middle-of-the-road rather than extreme proposals. One is a flat rate of 16 per cent of taxable income (as newly defined), a proposal that would commend itself to one school of tax reform-those who reject progression on ethical grounds or because it complicates the tax law and who would substitute a proportional tax on all income above a specified subsistence or modest level. This rate schedule would increase the effective tax rate on persons with income below $\$ 25,000$ and greatly reduce the effective rate on taxpayers with more than $\$ 50,000$ of expanded adjusted gross income. ${ }^{67}$ By contrast, the most progressive of the five PechmanOkner schedules (which includes a higher initial exemption or lowincome allowance than the others) would reduce the effective rate on taxpayers with less than $\$ 25,000$ of expanded adjusted gross in-

65. Pechman \& Okner, supra note 43 , at 24 (table 4).

66. Id. at 30-33.

67. $I d$. at 31 (table 11). "Expanded adjusted gross income" is adjusted gross income as defined in section 62 of the Internal Revenue Code modified to include the income items listed in Pechman \& Okner, supra note 43, at 23 (table 3). 
come and increase it for those above the $\$ 25,000$ level. ${ }^{.8}$ But these changes would be marginal rather than revolutionary when judged from a macroeconomic perspective. Taxpayers with expanded adjusted gross income of $\$ 50,000$ or more, for example, would pay only $\$ 2.6$ billion ( 2.5 per cent) more of the $\$ 103$ billion of income tax than under existing law. ${ }^{69}$

\section{Selective Tax Reform}

Comprehensive tax reform thus turns out to be only mildly redistributive if revenue is held constant, while if it is used to raise the promised $\$ 77$ billion of additional revenue by applying the existing rate schedule to the expanded tax base, only about 25 per cent of the new money would come from families with income above $\$ 50,000 .^{70}$ Can social reformers who have been led to believe that the systematic elimination of tax "loopholes" is a promising way to redistribute income or a bountiful source of financing for major new public programs salvage their objectives by abandoning the cause of comprehensive reform and concentrating instead on a limited list of targets? The most obvious strategy is to eliminate allowances that favor high income taxpayers, while allowing taxpayers in more modest circumstances to retain their tax shelters. The prime targets would be capital gains and such items of "preference income" as tax-exempt interest and percentage depletion. Once again, we find that the per-family impact of tax reform may be quite substantial, but that the aggregate result is not overwhelming. If reform is limited to the tax shelters patronized primarily by the rich, the aggregate amount of new revenue would be only about $\$ 13.4$ billion, of which $\$ 3.4$ billion would come from taxpayers with income below $\$ 50,000 .{ }^{71}$

68. Pechman \& Okner, "supra note 43, at 31 (table 11).

69. Id. at 26 (table 6), 38 (table A-7).

70. Id. at 26 (table 6).

71. The computation is as follows (all dollar amounts, except expanded adjusted gross income, in millions):

\begin{tabular}{|c|c|c|c|}
\hline \multirow{4}{*}{$\begin{array}{l}\text { Maximum tax on earned } \\
\text { income }\end{array}$} & \multicolumn{3}{|c|}{ Expanded Adjusted Gross Income Class } \\
\hline & \multirow[t]{2}{*}{ Under $\$ 50,000$} & $\$ 50,000$ \& over & Totals \\
\hline & & & \\
\hline & - & $\$ 112$ & $\$ 112$ \\
\hline $\begin{array}{l}\text { Realized capital gains } \\
\text { Constructive realization of }\end{array}$ & $\$ 1,686$ & 6,355 & 8,041 \\
\hline capital gains & 1,401 & 2,324 & 3,725 \\
\hline Tax-exempt interest & 112 & 974 & 1,086 \\
\hline Accelerated depreciation & & & \\
\hline \& depletion & 156 & 268 & 424 \\
\hline Totals & $\$ 3,355$ & $\$ 10,083$ & $\$ 13,988$ \\
\hline
\end{tabular}


Who are the upper-income taxpayers who would be the principal targets of selective tax reform (confined to capital gains, tax-exempt interest, and percentage depletion)? The new populists imply that the principal beneficiaries of these allowances are "tax millionaires" with such familiar names as Ford, Rockefeller, and Mellon-the "relative handful of Americans [who] are extravagantly endowed, like princes in the Arabian Nights Tales,"72 described in Ferdinand Lundberg's 1937 book, America's Sixty Families, and its 1968 sequel, The Rich and the Super-Rich.

But just as analysis of the $\$ 77$ billion of "tax welfare for the rich" distributed by the Internal Revenue Code disclosed that most of this amount is received by taxpayers in the middle and lower income brackets, so an examination of selective tax reform discloses that you don't have to be a Rockefeller to feel its impact. The reform program just described would affect about 825 thousand families, composed of 2 or 3 million individuals. The inhabitants of these top income brackets make up only 1 or 1.5 per cent of the population, and hence can be called a "relative handful," and they surely have more material goods than anyone at Haroun-El-Raschid's court. From a political perspective, however, it is misleading to imply that a tax reform program affecting more than 2 million people is aimed at "America's Sixty Families." I am in complete agreement with the objective of increasing taxes on this segment of our population, but the attempt to portray them as akin to Rockefellers and Fords is bound to be counter-productive.

\section{The Second-Order Effects of Tax Reform}

This analysis of the " $\$ 77$ billion welfare program for the rich" becomes even more sobering when a fact of life that $I$ have hitherto disregarded is taken into account. All of the estimates that $I$ have laid before you are derived by simple arithmetic. The Pechman-Okner study is based on a representative sample of tax returns, ingeniously augmented by estimates of items that are not now reported, to which the 1972 rate schedule was applied to estimate the changes in tax liability that would result from enlarging the tax base. But when items that are not now taxed are multiplied by today's rates, the

Figures are derived from computation done at Yale University based on the Peckman-Okner study; a copy of the computer printout is on file with the Michigan Law Review.

72. F. LUNDberg, ThE Rich AND the SUPER-RICH I (1969). 
product is a hypothetical amount that may vary substantially from the amount that will actually be due after the taxpayers have adjusted their financial affairs to the new law.

This is not the place, and I am not the person, to undertake an analysis of the second-order consequences of comprehensive tax reform. I will simply list some of the factors that would help to create a disparity between the estimate of $\$ 77$ billion of added revenue and the amount that might actually be produced by so sweeping a program.

First, if changes in the tax law have effects that are perceived to be adverse to activities that are now encouraged by tax incentives, Congress may respond by granting subsidies or other non-tax allowances as a substitute for the repealed tax incentives. Thus, some of the "new" revenue will simply be diverted to a partial restoration of the status quo ante. For example, repeal of the tax immunity of state and municipal bond interest is simply not in the cards without a substantial federal subsidy to the issuers to reimburse them for the higher cost of borrowing. Such a subsidy would absorb a substantial part of the new revenue, and, if it were generous enough, could cost the Treasury more than taxing the interest would produce. ${ }^{78}$ Similarly, one can hardly contemplate taxing social security benefits, public assistance, unemployment compensation, and some other transfer payments-as proposed by the Pechman-Okner study-without using a large part of the "new" revenue to increase these benefits. In other cases, the reform could hardly be enacted without offsetting tax concessions (e.g., the repeal of income-splitting for married couples would unquestionably require an increase in the personal and dependency exemptions), which would absorb the "new" revenue to a significant degree. While subsidies in some instances may be more equitable and efficient than the tax allowance they displace, ${ }^{74}$ the $\$ 77$ billion for new programs may be as evanescent as the "fiscal dividend" that was to be declared when we withdrew from Viet Nam.

73. See Fortune, The Impact of Taxable Municipal Bonds: Policy Simulations with a Large Econometric Model, 26 NATL. TAx J. 29 (1973). The Treasury estimated that the cost to it of tax exemption in 1968 was $\$ 1.8$ billion, of which $\$ 500$ million inured to the benefit of high-income individual investors, commercial banks, and casualty insurance companies. A private estimate for fiscal 1971 put these amounts at $\$ 3.3$ billion and $\$ 800$ million, respectively. See Hearings on S. 1015 Before the Senate Comm. on Banking, Housing \& Urban Affairs, 92d Cong., 2d Sess. 199, 277 (1972).

74. See Surrey, supra note 3. 
Second, the additional yield will be offset to some extent by revenue reductions in later years when the new structure has reached a "steady state." Thus, the denial of accelerated depreciation and of the deduction for intangible drilling and development expenses in the year of payment will increase the taxpayer's deductions in later years (e.g., for "dry holes" and losses when the property becomes worthless or is sold for less than its adjusted basis). These offsets are likely to be of more importance to high income than low income taxpayers.

Third, some taxpayers will shift to tax avoidance tactics that are not prohibited even by the comprehensive reform program, such as the deferral of earned income to later years, intra-family transfers of property, and investments in growth stocks and real property. The reader may be inclined to reject this suggestion, believing that Congress could be induced to define "income" in such sweeping terms as to outlaw all tax avoidance devices. ${ }^{75} \mathrm{He}$ would do well to remember the Duke of Wellington's response when an otherwise forgotten person accosted him in Hyde Park with the salutation, "Mr. Smith, I believe?" The Duke's reply: "If you believe that, you'll believe anything."

Fourth, major changes in the tax structure are bound to have an impact, however obscure and difficult to measure, on the taxpayer's economic choices-such as between work and leisure, between investment and consumption, between risky and safe enterprises-that will affect his pre-tax income, and therefore his tax liability.

Fifth, these changes in each individual taxpayer's economic behavior will alter the price of goods and services for other taxpayers who, in turn, will respond by changing their economic behavior; these decisions will alter their pre-tax income, and hence their tax liabilities.

\section{Summary and Conclusions}

In concluding this analysis, I should like to look once more at the " $\$ 77$ billion welfare program for the rich," this time from the perspective of the tax reform proposals offered to the electorate by Sena-

75. On the extent to which even the most dedicated and enthusiastic advocates of the broad Haig-Simons definition of "income" disagree about its application in practice, see Bittker, supra note 39. 
tor McGovern during the 1972 campaign. During the Democratic primaries, Senator McGovern espoused a plan that, for the first time in American history, would have brought rich and poor together into a single comprehensive program to tax persons above a specified break-even point and pay benefits to those below it. There were several versions of the plan, but the one that caught the popular imagination called for a "demogrant" of $\$ 1,000$ per person as assured income maintenance, to be paid in cash to those at the bottom of the ladder, reduced gradually for those at low and modest income levels by the amount of tax on their outside income, and credited against the tax liability of those with higher incomes. ${ }^{76}$

This integration of "positive taxes" with public assistance ("negative taxes") had many adherents in academic circles, uniting economists of such diverse political convictions as Milton Friedman and James Tobin, ${ }^{77}$ but the idea was unknown in the outside world. Lacking an infrastructure of public information and journalistic support, which could not possibly be supplied in the superheated haste of a primary campaign, the "demogrant" proposal quickly collapsed under stress. The reasons need not be recited here, save as they illuminate the main themes of this Article.

When first advanced by Senator McGovern, the $\$ 1,000$ tax credit proposal seemed to offer a way to redistribute income on a significant scale by taxing only the very rich, and thus to respond to such slogans as "take the rich off welfare." But a careful reading of Senator McGovern's own statement would have disclosed that "about 20 per cent of Federal taxpayers would experience a tax increase"78 -an estimate that was later revised upward to embrace about 90 million individuals, ${ }^{79}$ only a few of whom are named J. Paul Getty. Moreover, under the original McGovern plan a tax increase would be experienced by a single person with income of $\$ 2,000$ or more and a married couple without children if their income was $\$ 4,000$ or more.

Families with two or more children fared better under the plan, and its supporters pointed out that a family of four would pay less than under existing law unless its income exceeded $\$ 20,000$. It was impossible to focus solely on this idyllic and authentic American

76. McGovern, Tax Reform and Redistribution of Income, 118 CoNG. REc. S5626, S5628 (daily ed. April 7, 1972), reprinted in N.Y. Rev. of Books, May 4, 1972, at 7, 10.

77. See C. Green, Negative Taxes and the Poverty Problem 57-61 (1967).

78. McGovern, supra note 76, at $\$ 5628$, reprinted at 10.

79. Calculations made at Yale University. 
group, however, because in the California Democratic primary Senator Humphrey quickly made himself the standard-bearer for other American life styles. He exploited the plan's bias against unmarried persons and childless couples, asserting that it would produce a 50 per cent increase (from $\$ 1,100$ to $\$ 1,666$ ) in the federal income tax liability of an $\$ 8,000$-per-year unmarried secretary living in San Francisco $^{80}-$ a homely geographical touch that could have been amended to fit every city and hamlet in the nation. The charge, unconvincingly denied by Senator McGovern, was devastating; it would have been even more deadly if Senator Humphrey had had access to the computer printouts on the plan, ${ }^{81}$ showing an aggregate reduction of $\$ 100$ million in taxes for families with income of $\$ 1$ million or more and scattered reductions for many other high income taxpayers, attributable to the fact that the proposed top tax rate was 48 per cent.

Though Senator McGovern won the California primary, his narrow margin in a state that had been expected to give him a smashing victory was blamed in large part on the tax plan, which then went back to the technicians for revision. The intolerable bias against single persons and childless couples could be mitigated by changing the "demogrant" from a flat amount of $\$ 1,000$ per person and by distinguishing between adults and children (e.g., $\$ 1,320$ for the first one or two adults in a family, and $\$ 500$ for each child), but this change meant that many welfare families would be left below the poverty line and would get less in 1975 - the target date for a full employment economy-than their 1972 welfare payments, especially if the mother was the only adult. ${ }^{82}$ Moreover, this version of the plan was no more financed by the rich and the super-rich than was its predecessor. Almost one half of the nation's families, comprising more than a third of the population, would have paid more taxes than under existing law.

Once these deficiencies, along with others that need not be detailed here, were digested by Senator McGovern's advisers, the "demogrant" proposal was abandoned, and an orthodox tax reform program was substituted. It was limited to attacking such old favorites as long-term capital gains, percentage depletion, and accelerated

80. Washington Post, May 29, 1972, § A, at 12, col. 1 .

81. Calculations made at Yale University.

82. Retired persons living on social security benefits and homeowners also presented problems, for which McGovern's advisers sought to provide remedies that were not included in the original plan. 
depreciation, and the pill was sugar-coated with a proposed reduction of the maximum tax rate from 70 to 48 per cent. The target was $\$ 12.6$ billion of added revenue from the individual income tax ${ }^{83}$ well under 20 per cent of the legendary $\$ 77$ billion of tax welfare dispensed by existing law. By the time this plan was disclosed, however, the election was only two months off and, as we now know, victory for Senator McGovern was not at hand. In accepting the Republican nomination just a week before the revised McGovern tax plan was unveiled, President Nixon said that the original plan would add 82 million people to the welfare rolls. ${ }^{84} \mathrm{He}$ could have offered no more ironic an obituary to the "demogrant" proposal, which had been intended to bar the demeaning term "welfare". by bringing rich and poor together. The President simultaneously demonstrated that the term "welfare" as a label for tax allowances was a two-edged sword, tendered to him by a political opposition that did not realize which edge was sharper. We are still hearing reverberations of this tactical reversal. John D. Ehrlichman, former assistant to the President, has asserted that comprehensive tax reform means that "you don't let the average householder deduct the interest on his mortgage anymore, and you don't let him deduct charitable contributions to his church or to the Boy Scouts." 85 It is hard to deflate rhetoric of this type if one has been proclaiming that the deductions allowed by current law for local property taxes, interest on home mortgages, and charitable contributions are integral parts of a $\$ 77$ billion welfare program for the rich and the super-rich.

Despite this painful history, I am convinced that a comprehensive income-maintenance program, integrated with the federal income tax system, should be high on our national agenda. But the technical foundation for such an integrated program has only begun to be laid, and public acceptance of its cost is even further in the future. Macroeconomic estimates, in which a hundred million dollars is the smallest unit of calculation, are easily made, but the fiasco just described

83. N.Y. Times, Aug. 30,1972 , at 1, col. 8 , at 22, cols. 4-5.

84. N.Y. Times, Aug. 24, 1972, at 47, cols. 2-3. The estimated 82 million "on welfare" were evidently those who would receive some cash, however small the amount. If the President had accepted the broader theory of "tax expenditures" or "implicit grants" espoused by some tax theorists (Pfaff, supra note 3, Heller, supra note 3, Surrey, supra note 3 ), he could have said that the entire population, not merely 82 million people, would be on the welfare rolls. See McGovern, supra note 76, at S5628, reprinted at 10 . ("I propose that every man, woman and child receive from the federal government an annual payment.")

85. N.Y. Times, March 17, 1973, at 30, col. 2. 
shows that more is required than impeccable arithmetic. We must be clear about the effect of the program on the unmarried secretary, the policeman who moonlights as a taxi driver, the salesman who is married to a school teacher, the retired pharmacist living on social security, and so on. The technician may wish to drown these cases in a sea of averages, dismissing each inconvenient instance as idiosyncratic, but sooner or later the facts must be disclosed.

Of these facts, the most difficult to face is that the income pyramid gets narrower as it gets higher. The rich and the super-rich at the top make a convenient target for rhetoric, but most of the money is to to be found at lower levels. It is a counter-productive hoax to encourage the belief that $\$ 77$ billion can be raised by "taking the rich off welfare," if the term "rich" is to have the meaning ascribed to it by the audience to which this slogan is addressed.

In conclusion, the time has come to rescue the federal income tax from the superheated rhetoric of its populist friends. By denouncing it as a web of "loopholes," "organized larceny," a vast and uncontrolled program of "back-door spending," and a pork barrel of "upside-down subsidies," they threaten to persuade wage earners and other low and middle income taxpayers that the income tax is the worst of all possible taxes, while leaving its competitors-state sales taxes, local property taxes, and value-added taxation-stronger by comparison. By indiscriminately lumping together percentage depletion, income-splitting for married couples, the exemption of state and municipal bond interest, the extra $\$ 750$ exemption for the blind, accelerated depreciation, the exemption of social security payments, and so on, they imply that these features of existing law are equally objectionable, and that a tax reform proposal is a craven surrender to vested interests if it does not eradicate all of them simultaneously.

This implication cannot be faulted if it is what the populist critics of the existing law really mean. But for those who believe, as I do (and as I suspect the new populists, for all their rhetoric, do), that these "loopholes" can be ranged in a hierarchy-from offensive, through debatable and trivial, to justified-and that we would do well to pick and choose among them, the rhetoric I have described undermines rather than supports the cause of tax reform. If $\$ 77$ billion of new revenue comes to be the popular measure of serious tax reform, the revenue impact of any feasible program of selective reform is bound to be disappointing, even if it concentrates on 
capital gains, tax-exempt interest, accelerated depreciation, percentage depletion, and similar high-income provisions. In my view, therefore, the time has come for a drastic revision of the rhetoric of tax reform. 